\title{
High and Low Frequency Erosive and Constructive Cycles in Estuarine Beaches: an example from Garcez Point, Bahia / Brazil
}

\author{
ABÍLIO C.S.P. BITTENCOURT ${ }^{1}$, GUILHERME C. LESSA ${ }^{1}$, JOSÉ M.L. DOMINGUEZ ${ }^{1}$, \\ LOUIS MARTIN ${ }^{2}$, GERALDO S. VILAS BÔAS ${ }^{1}$ and FÉLIX F. FARIAS ${ }^{3}$ \\ ${ }^{1}$ Laboratório de Estudos Costeiros, CPGG, Instituto de Geociências/UFBA, 40210-340 Salvador, BA, Brasil \\ ${ }^{2} \mathrm{CNPq} / \mathrm{IRD}$ (Orstom), International Convention, Project AIMPACT \\ ${ }^{3}$ Instituto de Geociências/UFBA, 40210-340 Salvador, BA, Brasil
}

Manuscript received on December 6, 2000; accepted for publication on August 9, 2001; presented by KenITIRo SUGUIO

\begin{abstract}
Monitoring of the morphodynamic variations of the beaches associated with an estuary contiguous with Garcez Point, Bahia, Brazil, and the superposition of aerial photographs from the region, show the presence of distinctive erosive and constructive cycles of low and high frequencies. Between 1959 and 1989, one event of shoreline erosion and progradation was recognized on the oceanic beaches just outside the estuary. Inside the estuary, an erosion phase at the southern margin coincides with a constructive phase at the other side, and vice-versa. On the southern estuarine beach, low-frequency cycles of erosion and progradation are also perceived, but with the inverse trend when compared to the contiguous oceanic beach. During the beach monitoring period (February/1991 to July/1992), the oceanic beach showed retreat rates varying from $23.7 \mathrm{~m} / \mathrm{year}$, at the channel entrance, to $1.0 \mathrm{~m} / \mathrm{year}$, three kilometers away from it. During the same period, the estuarine beach advanced at a rate of $60.3 \mathrm{~m} / \mathrm{year}$. The long-term dynamics of the shoreline position in both sides of the estuarine entrance appears to be related to the position of the channel in the ebb-tidal delta.
\end{abstract}

Key words: erosive and constructive cycles, longshore sand transport, wave refraction, canyon, ebb-tidal delta, Bahia/Brazil.

\section{INTRODUCTION}

The estuarine system at the southwestern end of Todos os Santos Bay, between Itaparica Island and the mainland (Fig. 1), terminates in an ebbtidal delta characterized by various submerged sand banks. Historically, the beaches associated with this region have been subjected to erosive and constructive cycles of high (seasonal) and low (decadal) frequencies. Bittencourt et al. (1990), showed that high-frequency changes of the position of the shore-

Correspondence to: Abílio Carlos da Silva Pinto Bittencourt E-mail: abilio@cpgg.ufba.br line of Caixa-Pregos beach, located at the northern margin of the main estuarine channel (Fig. 1), are related to seasonal variations of the wave regime. These authors also show that the net longshore drift of sediment in the southern half of Itaparica Island is from NE to SW. In this study, the morphodynamic variability of the coastline at the southern margin of the estuarine channel was investigated in order to characterize the beach dynamics around and at the estuary entrance.

The estuary is part of Todos os Santos Bay (Fig. 1), an estuarine system with an area of ap- 

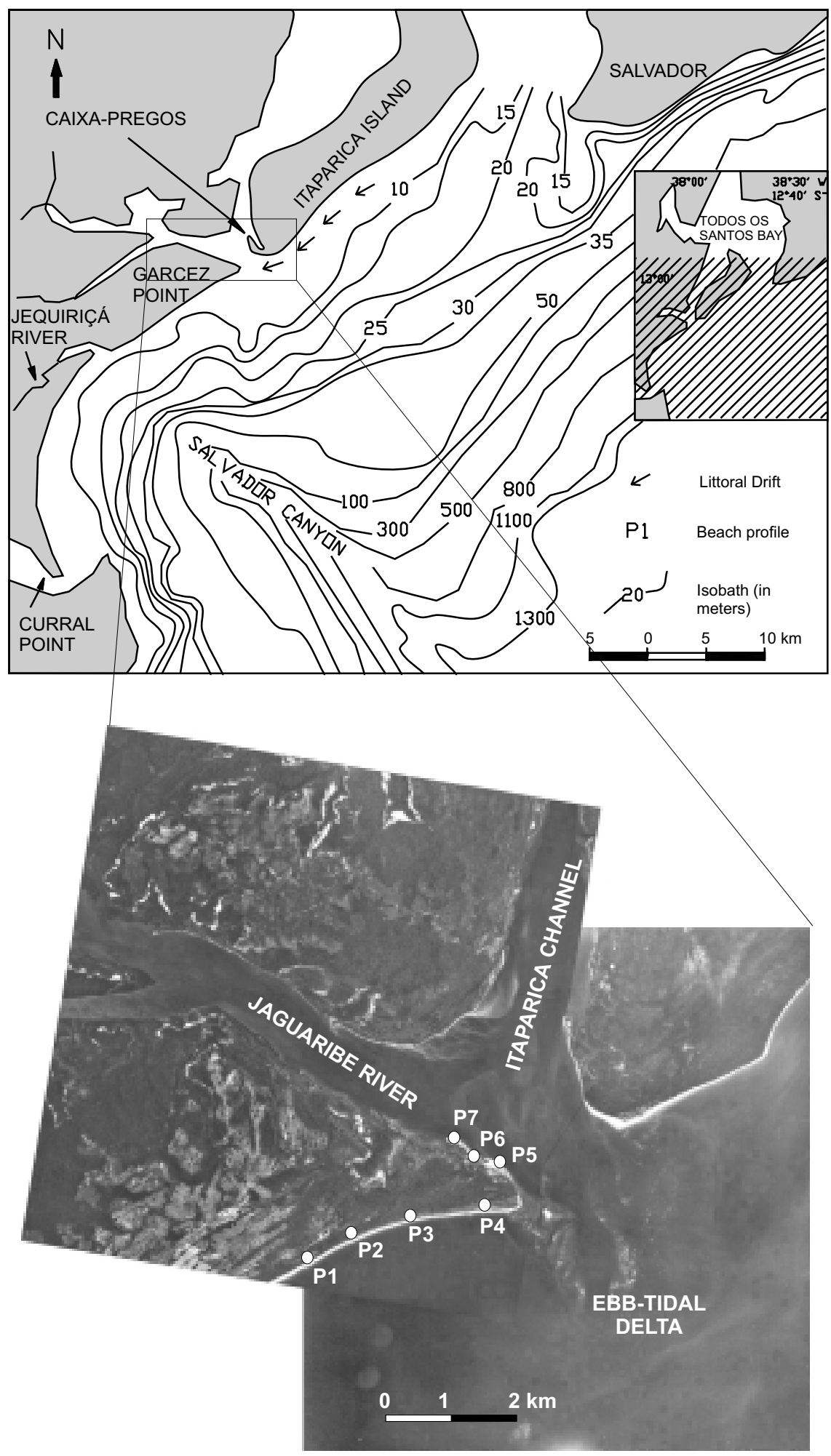

Fig. 1 - Location map of Garcez Point showing positions of the profiles. 
proximately $1100 \mathrm{~km}^{2}$ (Lessa et al. 2001). The estuarine system is ebb-dominated, as indicated by the $4 \mathrm{~km}$ long ebb-tidal delta, and subdivided into two distinct segments: the Itaparica Channel, and the Jaguaripe River. While the former presents an apparently insignificant fresh water discharge because of its small catchment area, the Jaguaribe River may freshen significantly during times of high river flow, which attains maxima of more than $300 \mathrm{~m}^{3} / \mathrm{s}$ (Fig. 2A). The local climate is warm and humid, with yearly average rainfall of about $1500 \mathrm{~mm}$ that tends to be concentrated between April and August, as can be seen from the timing of the highest average discharges from the Jaguaripe River (Fig. 2B).

The local ocean tidal range is $1.9 \mathrm{~m}$ during average spring conditions (Lessa et al. 2001). Inside Itaparica Channel a "tidal divide"' (meeting point for the two tidal waves approaching from the northern and southern extremes of the channel) situated about $10 \mathrm{~km}$ upstream from the estuary mouth (Fig. 1) limits the tidal exchange between the largest part of Todos os Santos Bay, in the north, and its southwestern sector.

The atmospheric circulation is controlled by trade winds, associated with the South Atlantic highpressure cell, and the periodical advances of the Polar Atlantic Front (Santos 1962, Bigarella 1972, Martin et al. 1998). NE and E winds are prevalent during the summer, whereas SE and SSE are more common during autumn and winter.

\section{DATA ACQUISITION}

Monitoring of the beach morphology on the northwest and southwest sides of Garcez Point was performed with detailed surveying of seven profiles normal to the beach (P1 to P7, Fig. 1), from the backshore to the low-tide water line. Between February/1991 and July/1992, 26 surveys were accomplished at each one of the profiles. The Meteorological Station of Salvador (Fig. 1) was the source of wind direction data.

Refraction diagrams for the ocean waves were produced with classical methods (CERC 1984) within a radius of $50 \mathrm{~km}$ from the estuary mouth, and drawn on a 1:308,000 nautical chart (DHN 1979). Refraction calculation was based on the period and height of waves approaching the coast from NE, E, SE and SSE directions (U.S. Navy 1978), which are the directions that are most effective in mobilizing nearshore sediments along the Bahian coast (Farias et al. 1985, Dominguez et al. 1992, Bittencourt et al. 1997). In order to represent the more common oceanographic conditions, it was considered that the most significant height and period for NE and $\mathrm{E}$ waves to be $1.0 \mathrm{~m}$ and $5 \mathrm{~s}$, and for SE and SSE waves to be $1.5 \mathrm{~m}$ and $6.5 \mathrm{~s}$. With these characteristics, NE and $\mathrm{E}$ waves would start to feel the bottom at depth of about $20 \mathrm{~m}$, and the SE and SSE waves at a depth of about $35 \mathrm{~m}$ (King 1972).

\section{WAVE REFRACTION PATTERNS AND LONGSHORE DRIFT}

Figure 3 shows refraction patterns for the abovementioned four wave directions and the likely net sediment transport direction induced by longshore currents. Figures $3 \mathrm{~A}$ and $3 \mathrm{~B}$ show that $\mathrm{E}$ and $\mathrm{NE}$ waves promote a longshore drift from Garcez point, either in the direction of profile 4 to 1 , or towards profiles 5 to 7. In contrast, SSE and SE waves generate a longshore drift in the direction of all of the profiles 1 to 7 (Figs. 3C and 3D).

The determinant factor in the wave refraction patterns south of Garcez Point is the Salvador Canyon (Fig.1). SE waves, and secondarily SSE waves, clearly diverge from the Jequiriçá River mouth due to the presence of the canyon head (Figs. 1 and 3 C, D). The rays of SSE waves noticeably tend to converge toward the monitored coastal stretch, due to the presence of a shoal at the adjacent shoreface (Figs. 1 and 3D). E and NE waves do not present well-defined refraction patterns because of the high angles at which they arrive at the canyon axis. Wave fronts generated by these winds do not markedly converge or diverge because of the high angles with which they approach the canyon axis (Figs. 1 and $3 \mathrm{~A}, \mathrm{~B}$ ). A small divergence of the $\mathrm{E}$ and NE wave rays is observed, however, at 
A

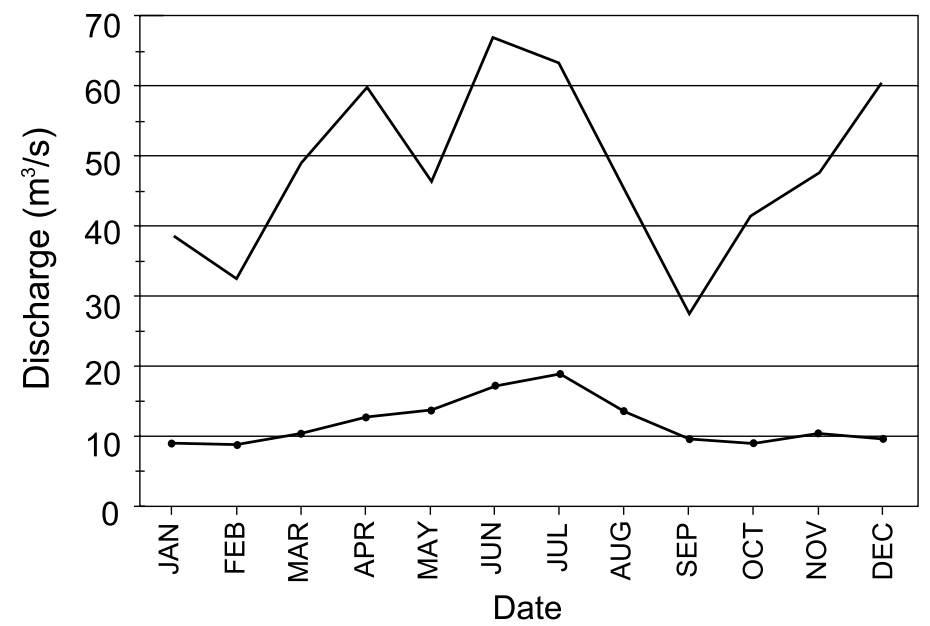

$\rightarrow$ month average $\quad$ - average month maximum

B

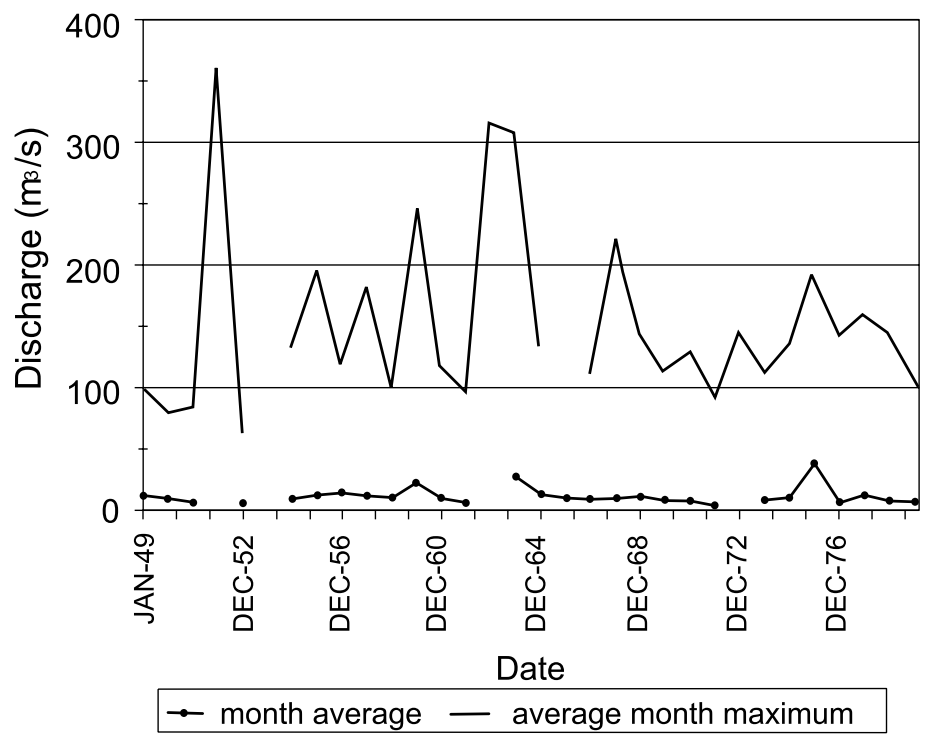

Fig. 2 - A) variation of the mouth average and maximum discharges for the Jaguaripe River, between 1949 and 1978, $30 \mathrm{~km}$ inland from Garcez Point. B) maximum and average mouth discharges for Jaguaripe River, $30 \mathrm{~km}$ inland from Garcez Point.

the canyon head fronting the Jeriquiçá River. The presence of the river mouth at this location not surprisingly coincides with the apparently lowest wave energy level along this coast, since wave trains from all directions diverge from this position.

\section{EROSIVE AND CONSTRUCTIVE CYCLES OF HIGH FREQUENCY}

Figures 4 and 5 represent the topographic variations observed in profiles 1 to 4 and from 5 to 7 , respectively. Isopleth diagrams in these figures show vari- 

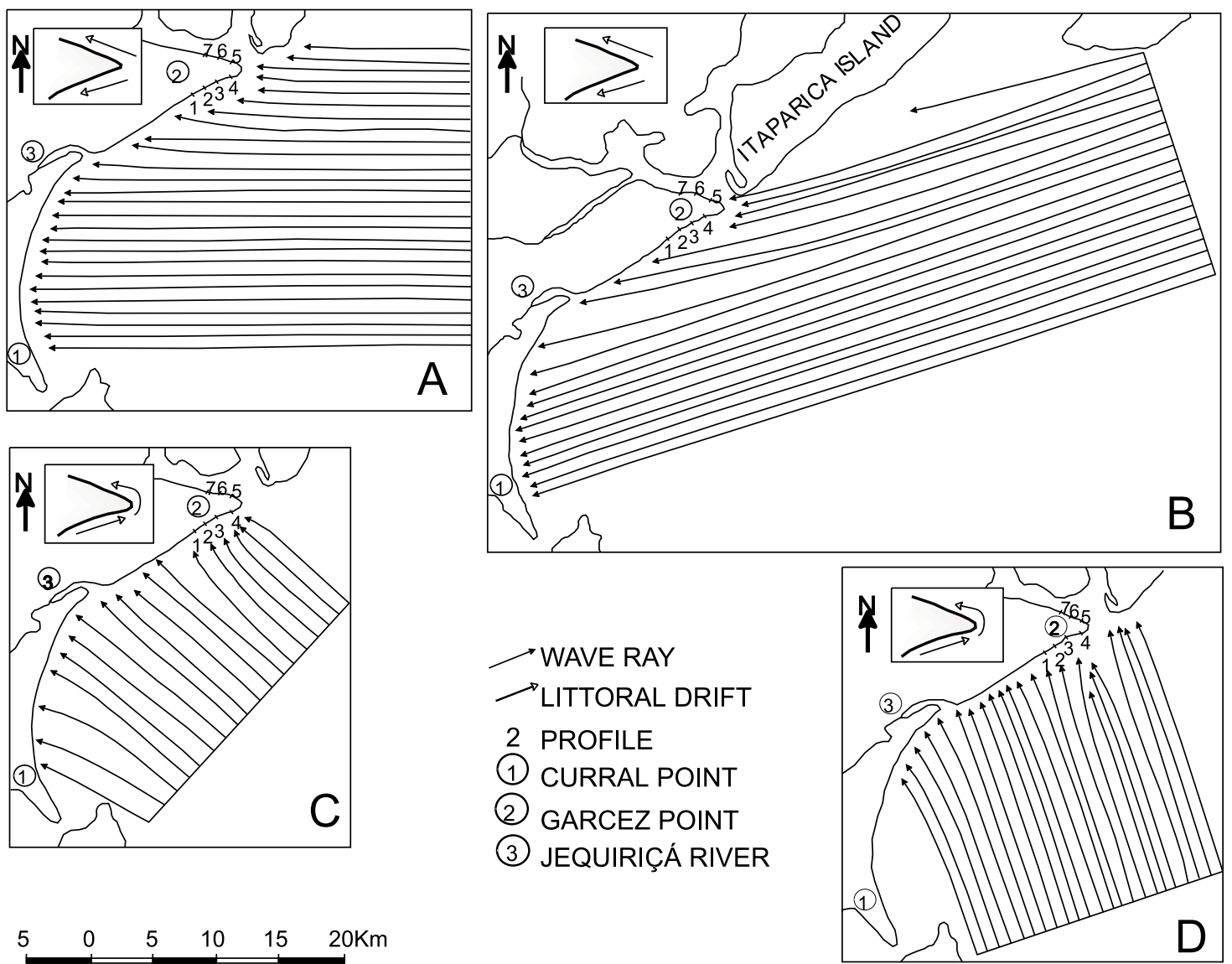

Fig. 3 - Refraction diagrams for waves with a period of 5 sec., from E(A) and ENE(B), and a period of 6,5 sec., from SE(C) and SSE(D). Inserts show the directions of longshore drifts induced by the wave fronts at Garcez Point.

ations of the beach topography through time, measured from a horizontal datum that intercepts the beach prism in the backshore. Thus, differences in elevation are negative. Isopleths connect equal elevation points relative to this datum.

Changes in the beach profiles are significant only in profiles 1 to 5 , inasmuch as profiles 6 and 7 , the farthest inside the estuary, were substantially stable during the monitoring period. Four distinct constructional-erosional phases can be distinguished in figures 4 and 5. Phase 1, from Feb. 1, 1991 to May 31, 1991, is characterized by erosion in profiles $1,2,3$, and 4 and, although subtle, by construction in profile 5. Phase 2, from May 31, 1991, to Sep. 12, 1991, is characterized by a more pronounced erosional event in profiles $1,2,3$, and 4 , and by a conspicuous construction in profile 5 . Phase 3, from Sep. 12, 1991 to Jan. 23, 1992, is characterized by a constructive event in profiles 1 , 2,3 , and 5 , and by erosion in profile 4 . Finally Phase 4, from Jan. 23, 1992 to July 23, 1992, is characterized by erosion in profiles 1, 2, 3 and 4, and by construction in profile 5 . These short-lived phases are encompassed by a general erosive trend, more evident in profiles 3 and 4 , and a constructive trend in profile 5 (Table I). 


\section{LOW FREQUENCY CONSTRUCTIVE AND EROSIVE CYCLES}

Superposition of aerial photographs of the estuary mouth taken at 1959, 1976 and 1989 reveals longterm changes on both sides of the estuary mouth (Figure 6). An erosive phase on one side appears to correspond to a constructional phase on the other side, and vice-versa. Between 1959 and 1976, a $120 \mathrm{~m}$ maximum seaward displacement of the shoreline southwest of the estuary coincided with a maximum shoreline retreat of $160 \mathrm{~m}$ northeast of the estuary. By contrast, the $320 \mathrm{~m}$ maximum retreat of the southwest shoreline between 1976 and 1989 stood in contrast to the $260 \mathrm{~m}$ maximum construction of the northeast shoreline.

Figure 6 also shows that, while apparently small changes of the shoreline occurred in the northern margin of the estuary channel, the southern margin experienced much more extensive retreat and construction of up to $240 \mathrm{~m}$. In agreement with the pattern of the shoreline behavior in profiles 4 and 5 (preceding section), the erosional phase in the oceanic beach between 1976 and 1989 was concomitant with a constructional phase inside the estuary.

\section{DISCUSSION AND CONCLUSIONS}

The contrasting behavior of the beach profiles outside and inside the estuary appears to be caused by waves generated by the SSE and SE winds, which are, according to Dominguez et al. (1992) and Bittencourt et al. (1997), those with destructive character along the coast of Bahia. These waves promote a longshore drift directed towards the estuary, as shown in figures $3 \mathrm{C}$ and $3 \mathrm{D}$. However, profile 5 , despite that drift, grows very little because the sediments that reach it are partially eroded by wave fronts coming from $\mathrm{E}$ and $\mathrm{NE}$ (Figs. $3 \mathrm{~A}$ and $\mathrm{B}$ ). Furthermore, in phase 2 most of the sediments eroded in profiles 1, 2, 3 and 4 (Figs. 4B to E) by the waves generated by the SE and SSE winds (Fig. 3A) seem to be deposited in profile 5 (Fig.5B). This is probably because the SSE winds in this phase were strongly influential (Fig. 4A), and that the same time no waves were generated by NE winds. In phase 3 there was a near absence of highly erosive SSE winds and waves (Fig. 4A) coupled with a great incidence of $\mathrm{NE}$ and $\mathrm{E}$ winds (Fig. 4A) that, according to Farias et al. (1985) and Dominguez et al. (1992), generate constructive waves. That explains why there would be a construction in profiles 1, 2 and 3 in this phase (Figs. 4B to D) as a result of sediment transport from of the shoreface to the beachface. Profile 4 continues to be eroded in this phase (Fig. 4E) because, despite the lack of SSE winds, the SE winds that occur in this phase (Fig. 4A) generate wave fronts that converge after they refract (Fig. 3C). In these circumstances, the wave heights increase (Zenkovitch 1967, Goldsmith 1976), with greater erosive power, when compared to wave situation in profiles 1,2 and 3 (Fig. 3C). In this phase, profile 5 presents a small increase (Fig. 5B), which must be made at the expense of sediment removed from profile 4 by the longshore drift induced by SE winds (Fig. 3C). Profiles 6 and 7 are practically unchanged through the monitoring time, which is ascribed to the reduced longshore sediment transport inside the tidal channel. Consequently, the flux becomes rapidly saturated with sediment, which causes deposition at the recurved spit, around profile 5, of almost the entire sediment load, according to mechanism discussed by Zenkovitch (1967).

Relatively higher instability of profiles 3 and 4 on the open coast can be related to the wave refraction pattern in the region, which tends to concentrate the energy of SE and SSE waves, in the vicinities of these profiles. Also, profiles 3 and 4 are probably more prone to erosion caused by flood tidal currents in the vicinity of an ebb-dominated estuarine mouth, as classically illustrated by the sand transport model of Hayes (1975).

Long-term progradation and retreat of shoreline position associated with ebb-tidal deltas have been well documented (Hine 1975, Oertel 1977, Finley 1978, Fitzgerald 1984, Smith and Fitzgerald 1994, Kana et al. 1999). Such changes are invariably associated with entrapment, and subsequent bypass of littoral drift sediment as it crosses an estuary 


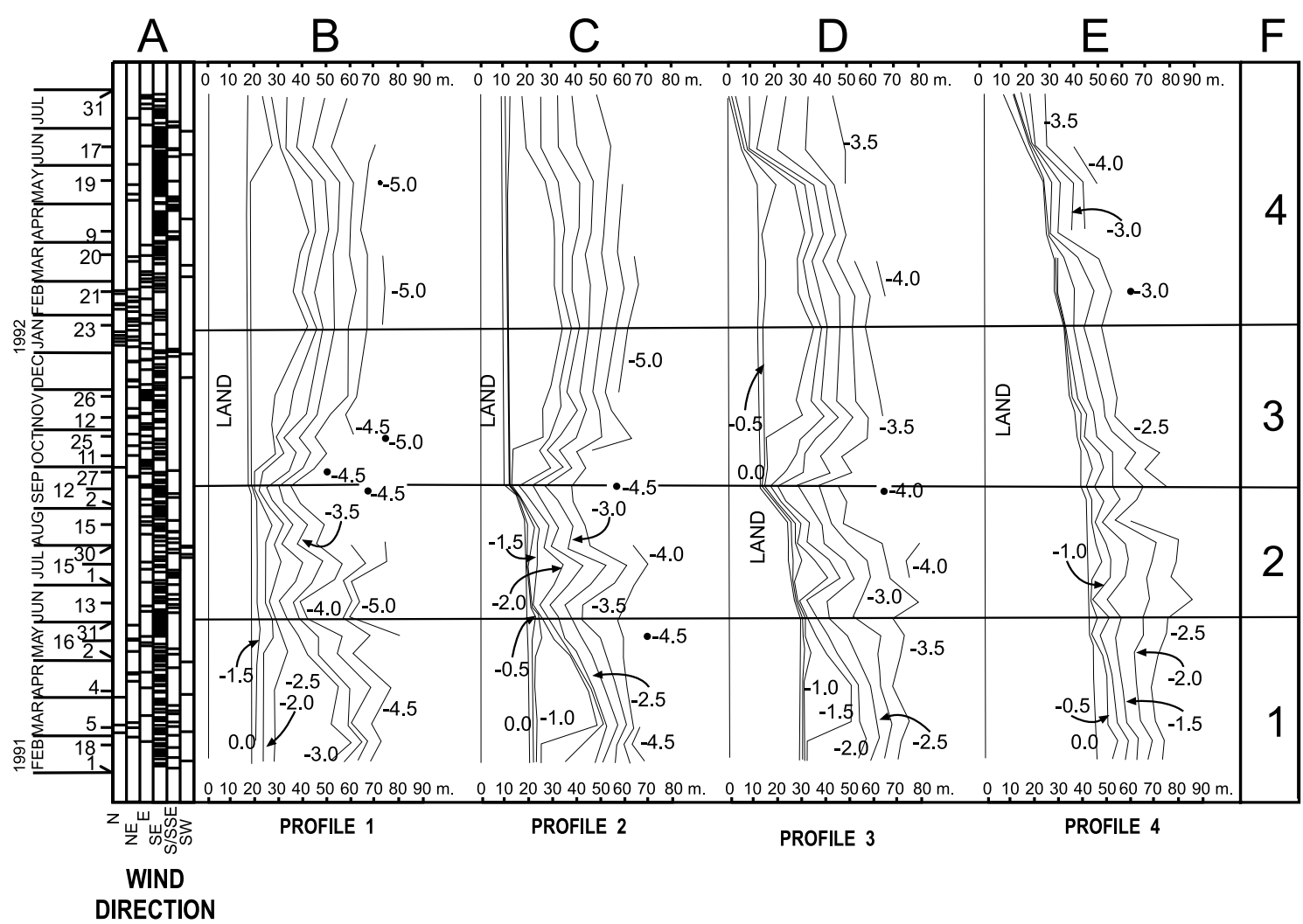

Fig. 4 - A) wind direction; B, C, D and E) isopleth diagrams for the profiles 1, 2, 3 and 4. The isopleths (in meters) connect equal elevation points at the beach surface, measured with time in relation to a datum passing along the backshore. Different phases of beach evolution discussed on text are also shown.

\section{TABLE I}

Total movement of the coastline, in meters, at profiles 1, 2, 3, 4, 5, 6 and 7 during the period from February/1991 to July/1992. For each profile, the yearly movement rate is also shown, in terms of retreat or advance.

\begin{tabular}{c|c|c|c|c}
\hline \multirow{2}{*}{ Profiles } & \multicolumn{4}{|c}{ Shoreline movement } \\
\cline { 2 - 5 } & $\begin{array}{c}\text { Total between Feb 1991 and } \\
\text { Jul 1992 (in meters) }\end{array}$ & \multicolumn{2}{|c}{$\begin{array}{c}\text { Annual rate } \\
\text { (m/ year) }\end{array}$} \\
\hline & Progradation & Retreat & Progradation & Retreat \\
\hline P1 & - & 1.5 & - & 1.0 \\
P2 & - & 6.0 & - & 4.0 \\
P3 & - & 27.0 & - & 18.0 \\
P4 & - & 35.5 & - & 23.7 \\
P5 & 90.5 & - & 60.3 & - \\
P6 & - & - & - & - \\
P7 & - & - & - & - \\
\hline
\end{tabular}




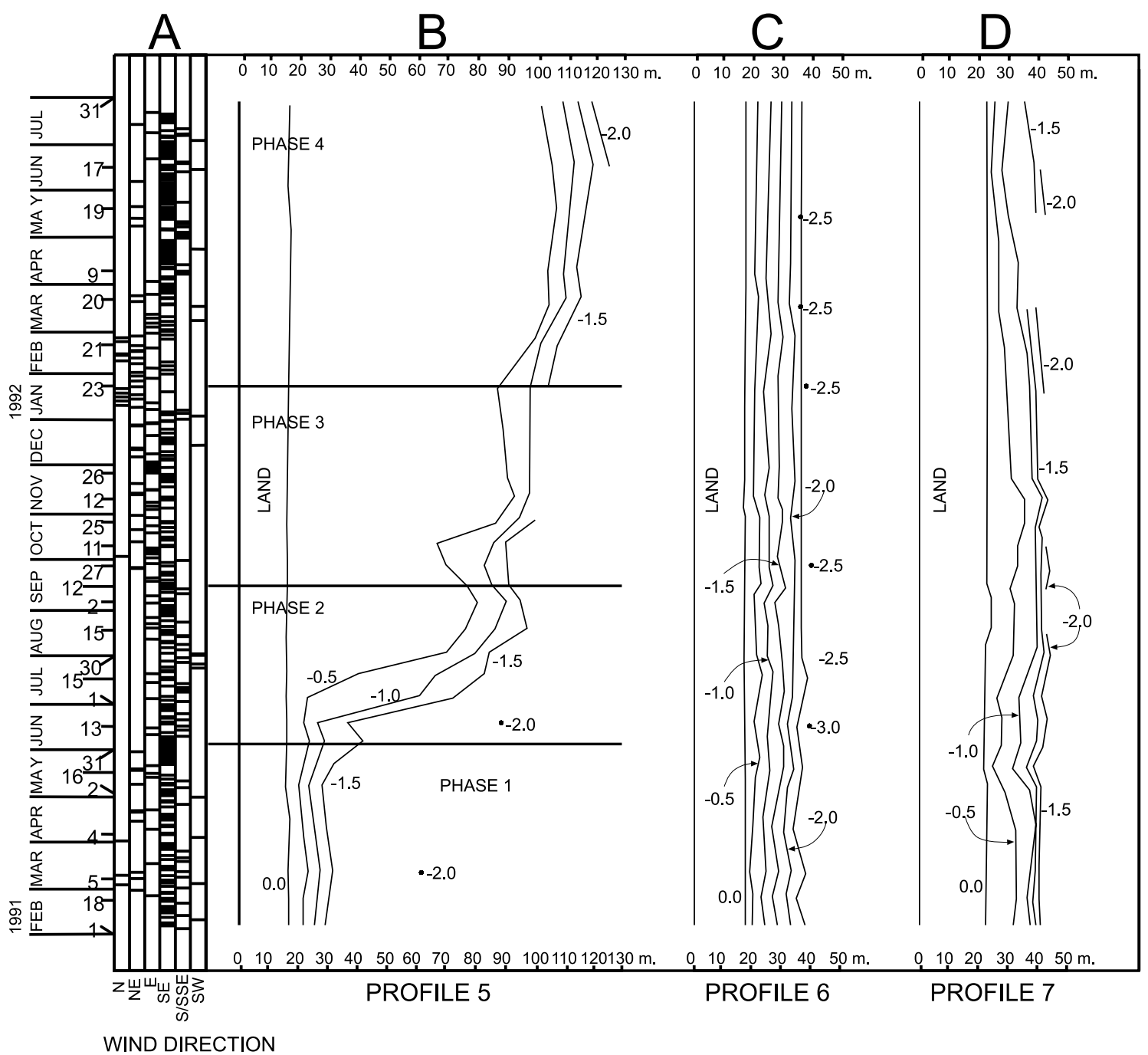

Fig. 5 -A) wind direction; B, C and D) isopleths diagrams for profiles 5, 6 and 7. Isopleths are described in Fig. 4.

mouth. Sandbars form where ebb-tidal currents balance with wave-generated, landward flows. Sandbar formation starts at the updrift side because of the hydraulic groin effect imposed by the strongest ebbing tidal-currents (Fig. 7A), favouring shoreline progradation. This temporary stockpiling of sand depletes the downdrift shoreline of sediment where erosion starts to occur. Further sediment accumulation updrift enhances downdrift shoreline erosion, enlarges the delta lobe and steers the main channel direction to downdrift (Fig. 7B). At this point, progradation in the updrift side stops due to easier sediment by- passing. A major bypass occurs when the channel breaches through a now shallower updrift lobe (Fig. 7C). As the bars make their way back to the shore, downdrift shoreline progradation occurs when the bars are welded to the barrier (or strandplain). At this point, there are fewer sand bars fronting the updrift shoreline, and an erosive cycle is established.

Long-term shoreline changes observed around the study area (Fig. 6) would be explained by this process. Each cycle of shoreline progradation and retreat can take several years, and is regulated by the estuary tidal prism and the volume of sediment 


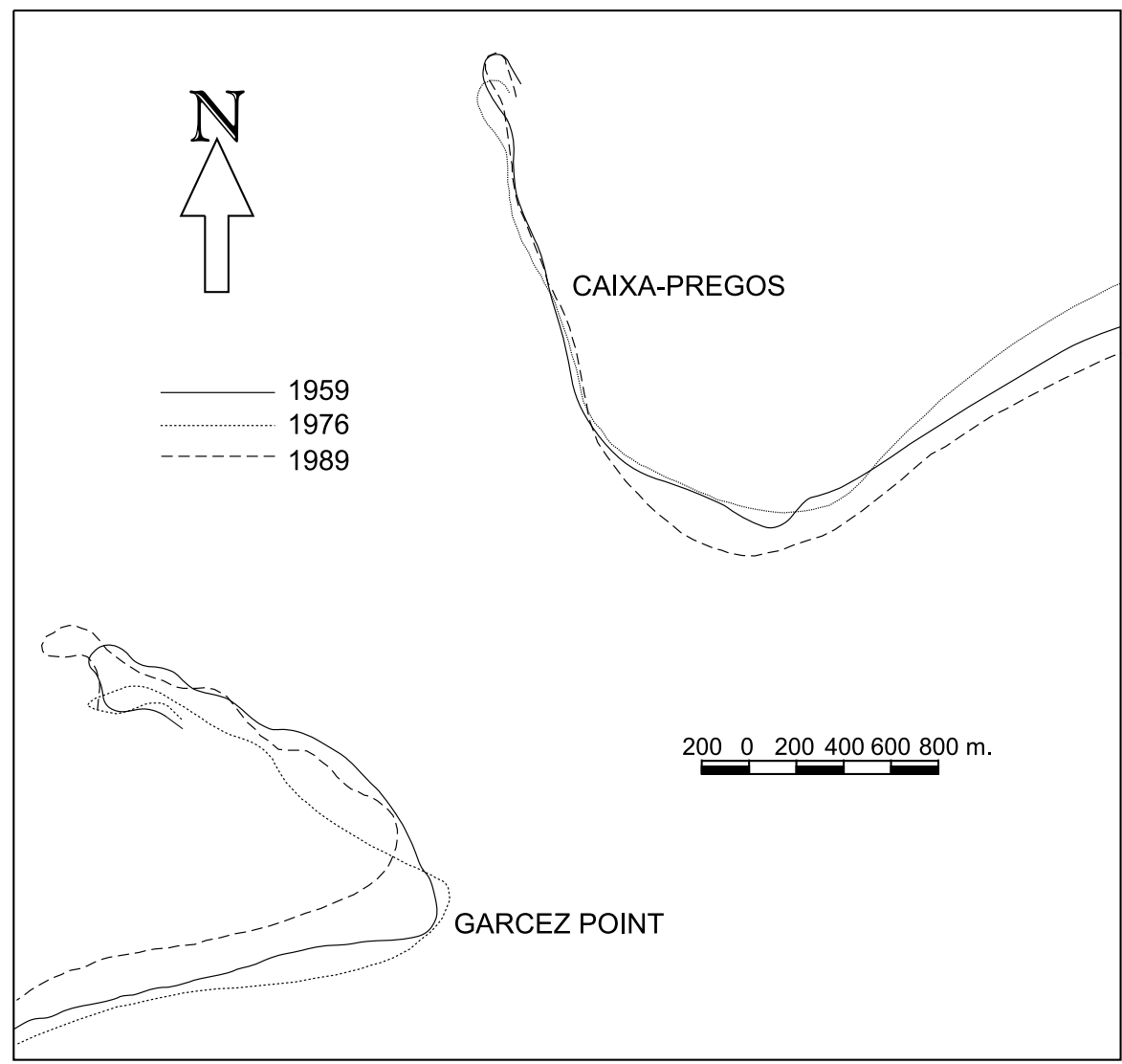

Fig. 6 - Coastlines associated with Garcez Point and Caixa-Pregos in the years 1959, 1976 and 1989.

retained in the ebb-tidal delta (Kana et al. 1999). Inasmuch as the longest observed cycle was completed in less than 10 years (Kana et al. 1999), we may assume that changes in the shoreline position observed in figure 6 , spanning 30 years, represent different stages of several cycles.

The closer the shoreline is to the delta, the more it is affected by the sediment-balance swing, especially because most of the sediment volume that comprises the delta recirculates within the delta itself, rather than moving downdrift (Smith and Fitzgerald 1994), ie., towards SW. This also can explain why profiles 3 and 4 , on the open coast, presented larger topographical variations.

The more stable position of the shoreline in the northeastern margin of the channel (around Cacha Pregos, Fig. 6) can be explained by i) its more in- terior, thus sheltered, position in relation to the offshore waves, and ii) to the likely more constant rates of longshore sediment transport at the updrift (NE) side of the estuary mouth. Conversely, the southwestern side is more affected by the impact of the SE and SSE waves and undergoes larger variation of the longshore sediment transport rate, which may explain the more pronounced variations of the shoreline position. With respect to the opposing shoreline trends inside and outside the estuary in the southwestern sector, there is still no clear comprehension of the processes involved, although abrupt changes in the rate of longshore drift in both sides.

Although no reliable data concerning the bathymetry, tides or tidal currents of the estuary exist, it is possible to estimate the tidal prism of the estuary by the projection of the tidal delta towards 

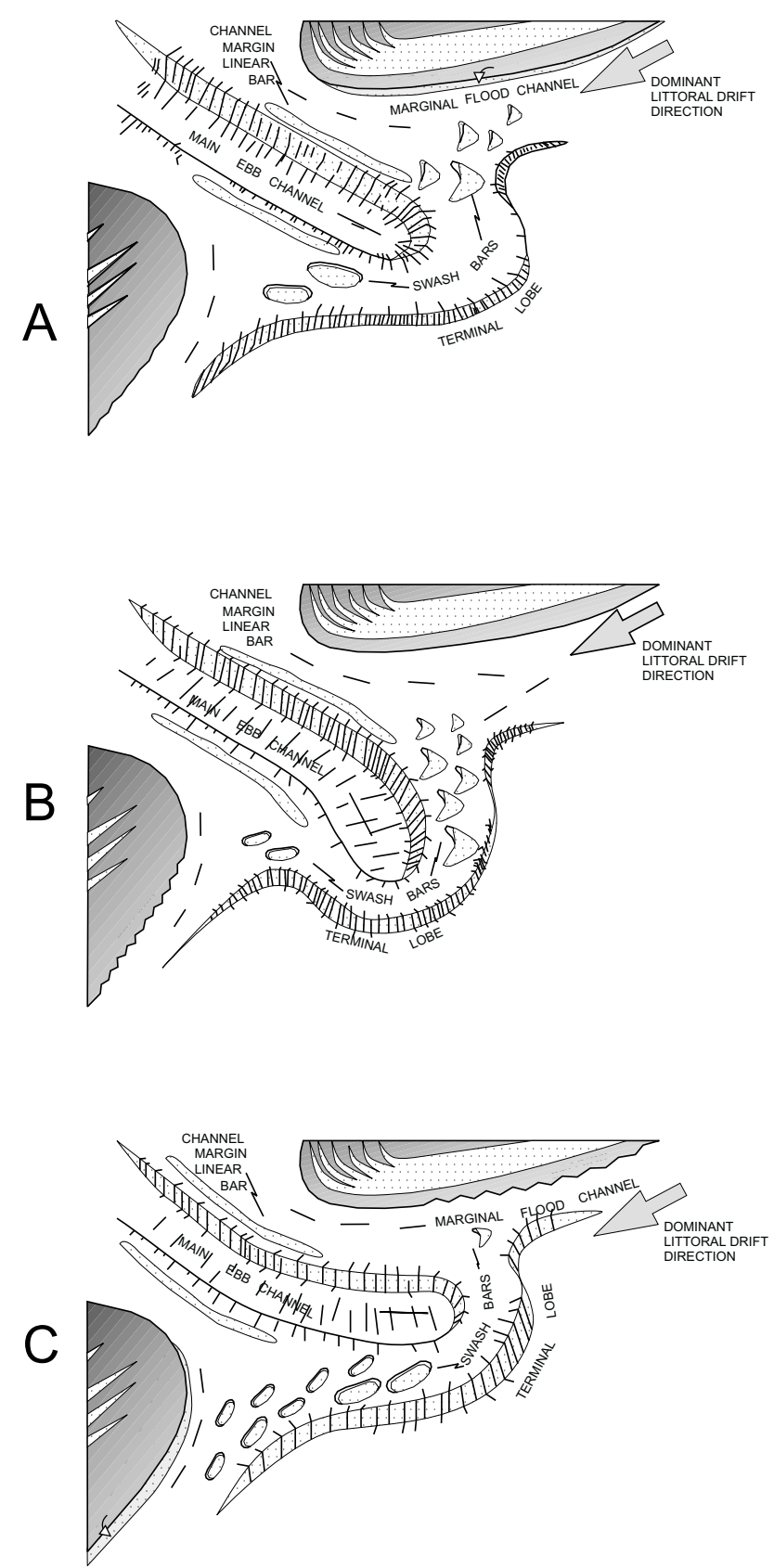

Fig. 7 - Schematic model of the morphology of an ebb tidal delta and changes in the orientation of the main channel due to the littoral drift and sediment bypass. A) sediment entrapment and growth of sand bars in the ufpdrift side favors progradation and starts erosion in the downdrift side; B) intense erosion occurs in the downdrift side due to the long-lasting entrapment of sand in the updrift side, which forces the channel to be steered to the south and interrupts progradation in the updrif side; C) the channel breaches through the northern side of the delta lobe and sediment is bypassed to the downdrift side, which starts a new progradational cycle. Erosion starts to occur in the updrift side until new sand bars are formed and more sediment is captured (modified of Hayes 1975). 
the ocean. Vriend et al. (1994), showed that a reasonable correlation exists between these two variables, and that the maximum projection of an ebbtidal delta $(\mathrm{Pr})$ could be calculated by the product $0.044 \times P^{0.6}$, where $P$ is the tidal prism. Knowing that the delta is projected about $4 \mathrm{~km}$ seawards from the coastline, the tidal prism would then be close to $1.8 \times 10^{8} \mathrm{~m}^{3}$. This value gives a tidal discharge that is more than 20 times larger than the highest measured discharge from the Jaguaripe River $\left(363 \mathrm{~m}^{3} / \mathrm{s}\right)$, or 600 times the average river discharge (Fig. 2A). Maximum registered river discharges in 1959 and 1976, when aerial photographs were taken, were $96 \mathrm{~m}^{3} / \mathrm{s}$ and $194 \mathrm{~m}^{3} / \mathrm{s}$, respectively. Despite the fact that river discharge was not measured during the monitoring period it is sound to suggest that river discharge plays a small, if not null, role in the dynamics of the shoreline.

\section{ACKNOWLEDGMENTS}

We would like thank to the helpful suggestions of an anonymous referee. ACSP Bittencourt, GC Lessa, JML Dominguez and GS Vilas Boas hold CNPq (Brazilian National Council of Research) research fellowships.

\section{RESUMO}

O monitoramento das variações morfodinâmicas das praias associadas com um estuário contíguo à Ponta dos Garvez, Bahia, Brasil, e a superposição de fotos aéreas da região, mostram a presença de distintos ciclos erosivos e construtivos, de baixa e alta freqüências. Entre 1959 e 1989, um evento de erosão e progradação da linha de costa foi reconhecido nas praias oceânicas fora do estuário. Dentro do estuário, uma fase erosiva na margem sul, coincide com uma fase construtiva no outro lado, e vice-versa. Na margem estuarina sul, são também percebidos ciclos de erosão e progradação de baixa freqüência, porém com um sentido inverso quando comparados aos da praia oceânica contígua. Durante o período de monitoramento das praias (fevereiro de 1991 a julho de 1992), a praia oceânica apresentou taxas de recuo variando de $23,7 \mathrm{~m} / \mathrm{ano}$, na entrada do canal, a 1,1 m/ano, três quilômetros distante do mesmo.
Durante o mesmo período, a praia estuarina avançou a uma taxa de 60,3 m/ano. A dinâmica de sedimentação de longo prazo em ambas as margens da desembocadura do estuário parece estar associada à posição do canal do delta de maré vazante.

Palavras-chave: ciclos erosivos e construtivos, transporte litorâneo de areia, refração de ondas, canhão, delta de maré vazante Bahia (Brasil).

\section{REFERENCES}

Bigarella JJ. 1972. Eolian Environments-their characteristics, recognition, and importance. In: RIGBY JK AND Hamblin WL (eds.). Recognitions of Ancient Sedimentary Environments. SEPM, Spec. Publ. 16: 12-64.

Bittencourt ACSP, Farias FF and Vilas Boas GS. 1990. Influência da deriva litorânea no desenvolvimento do esporão de Caixa-Pregos (Baía de Todos os Santos/BA). Rev Bras Geocienc, 20: 197-200.

Bittencourt ACSP, SAMPaio EES ANd FARIAS FF. 1997. Beach Imaging Through the Time Evolution of Topographical Profiles. Journ Coastal Research, 13: 1141-1149.

CerC (Coastal Engineering Research Center). 1984. Shore Protection Manual. US Army Corps of Engineers. Washington, DC, V.I, 597p.; V.II, 603p.

DHN (Diretoria de Hidrografia e Navegação). 1979. Carta Náutica $N^{\circ} 1110$ - Brasil Costa Leste: Do Rio Itariri a Ilhéus. Esc. 1:308.000.

Dominguez JML, BitTencourt ACSP and Martin L. 1992. Controls on Quaternary coastal evolution of the east-northeast coast of Brazil: roles of sea-level history, trade winds and climate. Sed Geol, 80: 213-232.

FArias FF, BitTencourt ACSP, Zanini A And DominGUEZ JML. 1985. Variações temporais e espaciais na dinâmica de sedimentação da praia de Armação, Salvador, BA. Rev Bras Geoc, 15: 48-54.

FINLEy RJ. 1978. Ebb-tidal delta morphology and sediment supply in relation to seasonal wave energy flux, North Inlet, South Carolina. Journ Sed Petrol, 48(1): 227-238.

FitzGerald DM. 1984. Interactions between the ebbtidal delta and landward shoreline: Price Inlet, South Caroline. Journ Sed Pet, 4: 1303-1318. 
Goldsmith V. 1976. Continental shelf wave climate models: a critical link between shelf hydraulics and shoreline processes. In: RA DAVIS, JR. (ed.). Beach and Nearshore Sedimentation. SEPM Spec Publ, 24: 36-69.

Hayes MO. 1975. Morphology of sand accumulation in estuaries: an introduction to the symposium. In: Cronin, LE (ed), Estuarine Research. New York, Academic Press, pp. 3-22.

Hine AC. 1975. Bedform distribution and migration patterns on tidal deltas in the Chatham Harbor estuary, Cape Cod, Massachussets, In: Cronin, LE (ed.), Estuarine Research. New York, Academic Press, pp. 235-252.

Kana TW, Hayter EJ and Work PA. 1999. Mesoscale sediment transport at southeastern US tidal inlets: conceptual model applicable to mixed energy settings. Journ Coastal Research, 15: 303-313.

KING CAM. 1972. Beaches and Coasts. Edward Arnold, London. 570p.

Lessa GC, Dominguez JML, Bittencourt ACSP AND Brichta A. 2001. The tides and tidal circulation of Todos os Santos Bay, Northeastern Brazil: a general characterization. An Acad Bras Ci 73: 245-261.
Martin L, Dominguez JML and Bittencourt ACSP. 1998. Climatic control of coastal erosion during a sea-level fall episode. An Acad Bras Ci, 70: 249266.

Oertel GF. 1977. Geomorphic cycles in ebb-tidal deltas and related patterns of shore erosion and accretion. Journ Sed Pet, 47: 1121-1131.

Santos RFA. 1962. Chuvas na Bahia. DNOCS, Bahia. $137 p$.

Smith JB ANd FitzGerald DM. 1994. Sediment transport patterns at the Essex River Inlet ebb-tidal delta, Massachussets, USA. Journ Coastal Research, 10: 752-774.

US Navy. 1978. Marine Climatic Atlas of the World, Volume IV, South Atlantic Ocean. Washington DC. 325p.

VRIENd HJ, BaKKer WT AND Bilse DP. 1994. A morphological behaviour model for the outer delta of mixed-energy tidal inlets. Coastal Engineering. 23: 305-327.

Zenkovitch VP. 1967. Processes of Coastal development. Oliver \& Boyd, London. 738p. 